Article

\title{
Re-Locating the Spaces of Television Studies
}

\author{
Anna Cristina Pertierra \\ School of Humanities and Communication Arts, Western Sydney University, Penrith, NSW 2751, Australia; \\ E-Mail: a.pertierra@westernsydney.edu.au
}

Submitted: 19 January 2016 | Accepted: 22 March 2016 | Published: 14 July 2016

\begin{abstract}
This paper will extend work originally presented in Pertierra and Turner's Locating Television (2013) to argue that the reasons for which the demise of television was prematurely assumed can be understood and corrected by critically examining the geopolitics of television scholarship. The spaces from which television has been taken seriously as a topic of investigation have enabled a neglect of empirical and theoretical research that genuinely engages with the ways in which television might be understood as variously surviving, growing, innovating and even leading the current and future global media landscapes. The paper offers two ways in which television scholars might productively re-locate their spheres of concentration to understand the diversity of television worlds today: 1) empirically, it considers the case of the Philippines where broadcast television is successful in ways that could only be dreamed of by television executives in the so-called 'world centres' of the global entertainment industry. 2) theoretically, the paper refers to complementary attempts in sociology, literary and cultural studies to offer alternatives to Europe and North America from which scholars might locate the vanguard for modernity, globalization and innovation. It is by engaging with both of these strands in concert-empirically investigating television beyond the 'usual places' in such a way that responds to the call of cultural theorists to question our very assumptions about where television studies' 'usual places' should be, that more nuanced understandings, and fewer premature declarations, might be made about what television is, and where it is going.
\end{abstract}

\section{Keywords}

entertainment television; television studies; Philippines; social media

\section{Issue}

This article is part of the issue "(Not Yet) the End of Television", edited by Milly Buonanno (University of Roma "La Sapienza", Italy).

(C) 2016 by the author; licensee Cogitatio (Lisbon, Portugal). This article is licensed under a Creative Commons Attribution 4.0 International License (CC BY).

\section{Introduction}

In recent years, growing numbers of media scholars, drawing from diverse examples around the world, have argued against the idea that the medium of television is in terminal decline. Certainly, in some places-most notably the United States - the models of free to air broadcasting through which much twentieth century media was both practiced and theorized have been seriously disrupted (see for example Katz \& Scannell, 2009; Spigel \& Olsson, 2004; see also discussion in Turner \& Tay, 2009). But around the world, and even within the United States, it has increasingly been recognized that television remains enduring in some ways, while changed in others (Pertierra \& Turner, 2013).
Understanding how television can be defined in the post-broadcast era has become more complicated, certainly (Turner \& Tay, 2009). But the new potential definitions of what television might today be, in some ways seem to have widened television's presence and grasp across a greater number of spaces than before: television can now be said to exist across multiple platforms and devices, it is accessed in multiple ways, sometimes simultaneously, at a wider range of times and across a greater proportion of the world than every before. Rather than rehearsing such debates, which have been discussed in my previous collaborations with Graeme Turner and are addressed in diverse ways across this special issue, this paper turns to consider whether there are ways in which television studies remains too 
narrow in scope, in particular by drawing from too narrow a set of global examples. It seeks both to look backward and critically ask how television might ever have been thought to be at an end, and to look forward at how television studies might proceed in the face of multiplied and diversified understandings of what television is and, particularly, where we should be looking for it. It extends work originally presented in Pertierra and Turner's Locating Television (2013) to argue that the reasons for which the demise of television was prematurely assumed can be understood and corrected by critically examining the 'geopolitics' (Mignolo, 2002) of television scholarship. The platforms and technologies through which audiences now find television are changing, but the concern of this paper is rather with revising the countries and communities which might be considered as spaces of innovation, beyond the previously imagined world centres of television practice and television theory. In particular, the example of the Philippines is proposed as a largely overlooked space in which broadcast television remains powerful, but in which new innovations for developing other platforms of television consumption are also being successfully explored. This case study of the Philippines is in itself a rich example to add to the growing field of television studies drawn from beyond the Anglophone West or the so-called Global North. Empirically, it offers evidence of the ways in which broadcast television continues to thrive in tandem with the arrival of new platforms such as social media and mobile technologies. But the case study also aims to provide a valuable lesson for television theory, illustrating how questions about the history and future of television can be shifted when we revise assumptions about where the 'centres' of television might actually be today, if indeed centres have ever been in any one place ${ }^{1}$.

If television is not yet dead-and if even apparently traditional broadcast television remains enduring in many parts of the world-it is worth considering why the question of television's demise has even been an important one in television scholarship of the $21^{\text {st }}$ century. Clearly, that debate was in large part shaped by transformations to television that were taking place in the United States and, in some different ways, in Western Europe. But it cannot be said that mainstream television studies were absent from or ignorant of nu-

\footnotetext{
${ }^{1}$ The case study selected for this paper was researched from June to December 2015 through the analysis of television episodes, newspaper commentary, and relevant social media feeds (the Twitter, Facebook and YouTube accounts of the Eat Bulaga program and television personalities Alden Richards and Maine Mendoza). The case study is underpinned by an ongoing research project on the cultural history of entertainment television in the Philippines, which was funded in 2011-2013 by the Australian Research Council Discovery Grant with Professor Graeme Turner at the University of Queensland (DP110100075).
}

merous serious and well-circulated studies of television from across the Americas, the Middle East, Asia and elsewhere (Curtin, 2010; Keane, Moran, \& Fung, 2007; Kraidy, 2010; McMillin, 2006; Sinclair, 1999; Straubhaar, 2007). Published in English with international readerships, such work has for some time now increasingly diversified the knowledge base from which media and cultural studies scholars are understanding their field globally, in addition to the many specific histories and debates that occupy national and regional networks of media scholars in different parts of the world. What Curran and Park proposed as the 'de-Westernization of media studies' (2000) was aided in part by a wave of interest from adjacent disciplines, including cultural anthropology, in the diverse social consequences of the growing presence of television and other media across different parts of the world (Abu-Lughod, 2005; Ginsburg, Abu-Lughod, \& Larkin, 2002; Mankekar, 1993; Rofel, 1994). These developments have made an impact, as Graeme Turner recently argued:

\begin{abstract}
"The de-Westernisation of media studies may still have some way to go, but media studies in the West is becoming more aware of the diversity of media systems around the globe-and that this diversity is constitutive, rather than just a passing phase in the inevitable evolution of 'their' system to become just like 'ours' as globalization kicks in. Pleasingly, we have moved beyond an assumption, implicit in much earlier work on television as well as on media cultures in general, that a focus upon the West or upon leading nations in Anglophone media studies would be enough to enable us to properly understand the function of the media, wherever it operates." (Turner, 2016, p. 127)
\end{abstract}

Progress in shifting attention outwards, to understand television across a wider range of spaces, is clearly important. But it does remain the case that the privileging of particular spaces from which the television industry has been taken seriously as a topic of investigation enabled a neglect of empirical and theoretical research that genuinely engaged with the ways in which television might be understood as variously surviving, growing, innovating and even leading the current and future global media landscapes. To put it another way, while television studies has moved along the path of diversifying the countries or regions in which it might be researched, the theoretical concerns of the global field have remained overly determined by the interests and trends of media in the (problematically-titled) Global North. It is timely to insist not only upon a globalized, diversified empirical base from which to account for contemporary television industries, cultures and practices-but actually to take seriously the possibility that television innovation, the futures of broadcasting, and the cultural practices through which we can theorise 
what television is and why it is important-can be driven from and by the (equally problematically-titled) Global South.

As discussed in the final section of this paper, across the humanities and social sciences a number of scholars and debates have grappled with similar questions within their respective fields: why do some places (usually Europe and the United States) become the spaces from which intellectual agendas, research directions, or historical transformations are formed? And how can such inequities in who gets to shape the questions or identify social innovations, be undone or reconstituted? Such questions go well beyond the specific parameters of television, but these broader reflections from other fields are useful for reflection and re-integration into the potential new spaces from which our understanding of television's pasts, presents and futures may emerge. This article offers a specific case study of a recent media event as one example of how empirical research can work to reorient television theory; in doing so it will consider how television producers continue to enthral their audiences in a place that rarely appears on the map of international television scholarship: the Philippines.

\section{Finding Television's Future in Overlooked Places: A Case Study from the Philippines}

The era in which broadcast television's decline was first beginning to be heralded in the case of the United States-from the 1990 s to the turn of the $21^{\text {st }}$ century-was precisely an era in which globalization, neoliberal reforms and technological changes were making a very different impact in the Philippines and many other places. Across a number of countries with developing economies, large urban populations, and regulatory reforms of privatization-including India, Mexico, Brazil, and much of East Asia-conditions were conspiring to produce some of the world's biggest television audiences, albeit in diverse conditions and with specific histories. As noted earlier, a body of television scholarship has documented these transformations in what led to an increasing and important globalization of media studies from which counter-narratives to the 'end of television' thesis have increasingly been drawn (Curtin, 2010; Keane et al., 2007; Straubhaar, 2007; Turner \& Tay, 2009).

Yet even while this scholarship flourished, the Philippines remained largely overlooked in recent analyses of global television (but see Ong, 2015). Such an oversight seems puzzling given the relatively long history and the on-going power of television as a mass medium across the Philippines' population of 100 million and a diaspora of more than 10 million overseas workers and migrants. The country's first broadcast took place in 1953, and within the following decade several key characteristics of the industry became consolidated in ways that continue to shape the nature of Philippine television today. The issuing of broadcasting licenses to elite family-led businesses ensured that, as with other media enterprises in the country, television ownership was controlled by a handful of powerful families whose vast interests across the national economy was matched by a deep involvement in national politics. Despite disruption to this model during a nationalized period under the Marcos dictatorship (1972-1986), in the post-Marcos era from the late 1980 s onwards, television stations were returned to the former model of operating commercially and competitively. Indeed, it was precisely in this period that Philippine television can be said to have flourished: whereas television had previously been mostly a middle-class affair, by the early 1990s broadcasting was reaching all but the most remote of rural areas. Also extremely important was the reach of television into the households of the urban poor, a community whose population had grown exponentially. This working class sector of the population, deeply immersed in everyday consumer culture of interest to advertisers, has become the definitive audience of popular Philippine television. The Philippine television industry, then, is similar to a number of other large and emerging economies in which broadcast television continues to dominate the media landscape, reaching the vast majority of urban and rural households and attracting more than $75 \%$ of nationwide advertising revenue ${ }^{2}$. While the Philippines does not have a direct of equivalent of Brazil's Globo or Mexico's Televisa empires, single players who capture most of the television ratings, there are two market leaders who between them take more than $80 \%$ of market share (Soriano et al., 2015, p. 2). Managed by members of the same elite families who founded them, or by a handful of their immediate associates and successors, the rival companies operating these two channelsABS-CBN and GMA 7-each have extensive networks of local television and radio interests in addition to other subsidiaries across media, entertainment and telecommunications. In a situation that parallels the story of broadcast television in Mexico (Pertierra \& Turner, 2013), these channels and the family-led companies that own them are not faceless private commercial broadcasters, but are deeply immersed in the building of national communities, whether through such company mottos as being 'in the service of the Filipino', through their highly-publicised philanthropic activities (Ong, 2015), or through their deep interconnections with the political process.

At first glance, the continuing power of free to air television in a country like the Philippines may seem

\footnotetext{
2 World bank data lists television ownership between 20052012 as being $74 \%$ of the population (World Bank, 2015) while other sources put it at around $90 \%$ of households (Soriano, Lim, \& Rivera-Sanchez, 2015).
} 
outdated or somehow 'behind' other media industries in which television was presumed to be in decline. But far from being old-fashioned in their centrality to the modern Filipino nation-state, television broadcasters in the Philippines, and the most successful productions that make up their programming, have been extremely successful in harnessing new technological developments to consolidate and expand upon their enduring success in the post-broadcast era. There are several reasons for this; certainly the relevance of the oligarchic control that cuts across media, politics and other industries of the Philippines should not be underestimated. Indeed, the limited number of players in the game of politics and business that Benedict Anderson (1988) described as a 'well-run casino', has enabled the market leaders to control and at times curtail the entry of rival platforms into the Philippine market. Cable subscriptions and direct to home satellite services have remained relatively low at 1.5 million and about 100,000 subscribers respectively in 2010, and offer little threat to broadcast television (Periabras, 2015). But even if they did gain pace, they are largely owned and operated by subsidiaries of the major broadcast television companies. Emerging platforms that offer substantially more promise for new or shifted television audiences-particularly the smartphone as a vehicle for the consumption of mobile television content-are similarly being unrolled through consortia that comprise the same group of key players who have dominated the media and telecommunications landscape, more or less since their inception.

In the case of the Philippines, it could be argued that the very stranglehold that 'old' broadcast interests continue to exert on the national media landscape has offered possibilities for quite a smooth transition to a converged media-telecommunications industry, precisely because it is unlikely to represent any serious disruption to the political economy of either industry. Market leader ABS-CBN has established subsidiaries to move into the telecommunications market, while also providing mobile accessible versions of their television content to subscribers (Enterprise Innovation, 2014; Paul Budde Communication, 2014). ABS-CBN excels in digitizing both old and new content produced for free to air broadcast for distribution across their multiple platforms and channels, both national and global. But the development of particular importance in the Philippines, and one which alerts us to the benefits of looking for innovation in overlooked places, is the growing role of mobile media in a country where mobile phones have reached an ownership rate of more than $110 \%$ (Paul Budde Communication, 2014). As the following case study indicates, television producers in the Philippines are keenly alert to the ways in which social media and mobile technologies have transformed the media practices of their audiences, and far from fearing such transformations, they have found ways to harness new media practices and re-integrate them into deeply traditional genres of free to air programming.

\section{Television Goes Viral: The Case of Eat Bulaga and the 'AlDub' Phenomenon}

In 2015, one of the Philippines' longest running television programs, a noontime variety entertainment show called Eat Bulaga, was responsible for the largest ever number of tweets to be sent to a specific hashtag. On Monday 26 October, a world record of 41 million tweets were sent with the hashtag \#AIDubEBTamangPanahon, referring to a live charity concert being held to celebrate the face-to-face meeting of a young couple who had 'fallen in love' while appearing onscreen during the television show. The story behind the love match popularly known as AlDub (a combination of the young man's name, Alden, and his female admirer's character, Yaya Dub), is worth telling in some detail. Until July 2015, Alden Richards was a Filipino actor and television host with a moderate following, a recent addition to the large and rotating ensemble of presenters on Eat Bulaga. This television program has broadcast live, six days a week, since 1979, attracting consistently high ratings and propelling multiple generations of comedians, models, actors and musicians to fame. The program is intentionally improvisational in tone, comprising games segments, comedy sketches, and song and dance numbers. Hosts interact constantly with the large excited audiences, as well as with one another, and much of the program's humour comes from the adlibs and the 'mistakes' that occur within a chaotically rich layering of noises, colours and movements.

Most of Eat Bulaga is filmed with a live studio audience in a former cinema in the north of Metro Manila. But one of the show's most popular segments has, for several years, been filmed in the streets of a different low-income neighborhood each day. Until recently, this outdoor segment was hosted by three popular comedians, who would joke with local residents, and banter via a live cross with the primary television hosts back in the studio. From July 2015, however, they were joined by a woman, Maine Mendoza, whose self-produced videos using the mobile application Dubsmash had gained her a sudden and massive social media following $^{3}$. A few months before being recruited to Eat Bulaga, Mendoza had posted a video compilation to her Facebook account, in which she mimed to audio samples of the famous Philippine actress (and sister to the President) Kris Aquino. Within a day the video had been viewed more than one million times, and the attention initially generated by viral videos on Mendoza's social media accounts quickly spread to national press, radio and television coverage. Eat Bulaga cast Maine

${ }^{3}$ Dubsmash is a mobile application that allows people to film short videos of themselves miming to famous audio samples. 
Mendoza to take part in an improvised segment that was a soap opera parody; she played Yaya Dub, a young and innocent companion (half caretaker, half housemaid) to a demanding older woman, played by male comedian Wally Bayola in drag. Yaya Dub does not speak, and only mimes to songs and audio snippets in keeping with Mendoza's original rise to fame as the 'Queen of Dubsmash'. Her charm and physical comedic abilities struck a chord with audiences, and producers of Eat Bulaga capitalised on this popularity by expanding her role in the outdoor segment, which is performed live and largely improvised in streets and houses of different low-income communities.

Soon after her addition to the show, it was revealed that Yaya Dub (and, the audience is led to believe, perhaps Maine Mendoza herself) had a crush on Alden, whom she had never met, but had only seen onscreen. As Alden and Yaya Dub, amidst much joking and teasing from the co-hosts, began to flirt with each other during live crosses between the outdoor location and the indoor studio, television audiences at home became transfixed by their courtship. Prohibited from meeting or speaking, Yaya Dub and Alden communicated only through holding signs, or miming to songs and audio grabs. Soon the Eat Bulaga production team had built their love story into the ever-more-popular soap opera parody segment of their show. As the weeks drew on, from July to October, the 'love team' known as AIDub were faced with obstacle after obstacle, prevented from meeting, but increasingly amorous in their non-verbal communications. While television ratings for Eat Bulaga boomed, it was the social media fascination of the AlDub phenomenon that was especially noteworthy, with 26 million \#AIDub tweets in the leadup to the couple's meeting, and between one million and three million views of videos for many of the daily videos posted to Facebook from the Eat Bulaga account. The October 2015 live concert, for which more than 55,000 tickets sold out in two days, was judged by some media commentators as the high point of the AlDub craze in the Philippines. But the producers of Eat Bulaga continued to develop new directions in which to build upon the popularity of Maine Mendoza and Alden Richards, including a spin-off scripted series in addition to the live appearances and substantial social media activities with which both are regularly engaged.

Eat Bulaga is certainly not what is typically defined in television studies circles as quality television. But the speed with which the production team capitalized upon the AIDub phenomenon is indicative of the production team's competence and expertise in achieving what makes the program so highly successful. Eat Bulaga relies on its longstanding and predictable structure that makes it deeply predictable to audiences, who know that on any given day, the order of segments and the types of activities to be found onscreen will be largely consistent. But within this predictability, producers and performers constantly improvise and interact with their audience. While the interactivity of Eat Bulaga hosts in previous decades was largely restricted to engaging with an enthusiastic studio audience, from the 2000s onwards it became increasingly possible for interactivity to include mobile production teams outside the studio, text messages from viewers, video submissions, and an increasing mobilization of social media to encourage participation from audiences. As of 2015, Eat Bulaga has more than 11 million followers on Facebook, where videos and photographs are posted daily, and a mobile application for people to watch videos on their smartphones. As a television show, Eat Bulaga is flexible, innovative and responsive to technological changes in its industry, while retaining the enduring core of what makes broadcast television so powerful. Rather than becoming fragmented or diminished by the rise of social media and mobile content, it harnesses content and mobilises audiences in such a way that the daily TV program could best be seen as the core product which defines a brand with multi-platform reach.

This capacity to be responsive, innovative and participatory is however not a result of Eat Bulaga being a new form of television. On the contrary, the style and structure of Eat Bulaga has deep roots in the genre of variety entertainment, drawing from the pre-television heritage of popular radio shows and vaudeville (Enriquez, 2008, pp. 88-127; Fernandez, 1996, p. 20). These traditions, with their focus on improvisation and interaction, are perfectly matched to the new age of television, as producers and performers draw the ingredients for new content from virtual or mediated audiences in much the same way that they have always done with their live or studio audiences. Just as the comedians who host Eat Bulaga onscreen are constantly observing, provoking or teasing their interlocutors from the audience in order to make audiences laugh, the program's production staff are also constantly looking for new ideas from social media feeds, and scanning the reactions of their audience online as much as in studio to encourage participation or provoke new creative directions. In the case of Indian reality television, Arvind Punathambekar (2010) has argued that participatory television cultures are engaging with mobile media technologies in ways that generate potentially new, or renewed, modes of public interaction. In the case of the Philippines, it is abundantly clear that the sort of mediated participation Punathambekar productively describes as 'mobile publics' is not only making television successful in the contemporary media landscape, but is also drawing upon television producers' long and deep understanding of how to produce participatory audiences. Although the mobile technologies may be new, the television production practices they are enabling have long been at the heart of successful entertainment television. 
In the case of the Philippines, the success of television programs like Eat Bulaga in harnessing the power of social media and mobile technologies can also be understood by acknowledging the Philippines' pioneering role in the take-up of the mobile phone. In the field of mobile media studies, the Philippines has been recognized as a place in which a number of cultural, technological and economic factors converged to integrate the use of mobile phones, for SMS texting rather than for voice calls, much earlier and more successfully than many other markets in the world (Pertierra, 2014). Indeed, the global history of mobile phones is instructive for television scholars trying to re-locate the spaces and places of their own field: the very mobility of mobile media-that it is cheap, portable, and relies on new commercial infrastructures rather than stateprovided national infrastructures-meant that the global development of mobile phone businesses and mobile media cultures was led not from the United States, but from such diverse places as Ghana, India, Indonesia, Korea, Finland-and the Philippines (Goggin \& Hjorth, 2014; Katz \& Castells, 2008). In the field of mobile media studies, it was never really possible to imagine that the 'centre' of mobile phone development was the United States or the United Kingdom. Scholars interested in any development of mobile technologies, whether that be the industrial or regulatory conditions of mobile telephony, or the political consequences for a mobile connected public, or in the many cultural consequences that range from family relations to sexual identities, have been obliged to understand the multiple and contingent contexts through which this technology of the mobile phone has been fundamentally constituted. Mobile media studies, then, did not have same degree of the opportunity that television studies did, to imagine one 'world centre' from which research agendas could be set. This difference in perspective may largely be a result of the time at which the technology took off. But the example of mobile media, and the places (such as the Philippines) in which mobile media seem to be enhancing rather than detracting from the power of television, is suggestive of the benefits that come from correcting the historical focus of television studies on the Anglophone West. To understand the future of television, we not only need to look more broadly afield, but also to question how we may have overlooked important elements in television's past.

\section{4. (Not Yet) The End of Television Studies: So What Comes Next?}

At first glance, a comedy show in the Philippines may have seemed an odd place from which to develop an argument about the enduring presence of television. But this example is illustrative of the research questions that emerge differently in television studies de- pending upon where you look (Pertierra \& Turner, 2013, p. 15). Exploring overlooked places to better understand television offers value both empirical and theoretical; empirically, it unfolds new chapters in the global history of how television industries have developed, and gives us additional insights into the ways that television broadcasters are adapting to digital and multi-platform environments in relatively successful ways. The case study of the AIDub phenomenon is not presented in this paper as necessarily representative of how television is changing in the contemporary world; however it is one extremely successful example of the wide range of ways in which broadcast television is adapting to and allying with other media platforms according to specific national and regional contexts. The AIDub phenomenon and the Eat Bulaga program may be seen as a vanguard case of how innovative uses of social media in television are developing in corners of the global television industry that only rarely garner attention from international scholars.

But this case study also alerts us to broader theoretical implications for the research agenda of a field such as contemporary television studies that aims to be global. To understand some of these implications, the final section of this paper turns to a brief consideration of a number of attempts across the humanities and social sciences-some of which have taken place in conversation while others have developed in parallelin rethinking how we might account for the global transformations of the modern era. Such attempts aim to reveal and challenge the ethnocentric premises upon which many debates across anthropology, sociology, literary and cultural studies (to name just a few examples) have been constituted (Alvarez, Arias, \& Hale, 2011; Comaroff \& Comaroff, 2012; Connell, 2007; Mignolo, 2011). Manifesto-like in tone and intended as interventions into their respective fields, what many of these examples share is a concern with what Mignolo has described as a 'geopolitics of knowledge' (2002): the ways in which forms of knowledge from certain places have become privileged over others as a result of global modernity and coloniality. The social sciences, even in their most critical and reflexive attempts, for Mignolo are nevertheless deeply ethnocentric; he argues that:

\footnotetext{
"It is no longer possible, or at least it is not unproblematic, to 'think' from the canon of Western philosophy, even when part of the canon is critical of modernity. To do so means to reproduce the blind epistemic ethnocentrism that makes difficult, if not impossible, any political philosophy of inclusion. (Mignolo, 2002, p. 66)"
}

From a different intellectual trajectory but along some similar lines, Raewyn Connell's Southern Theory offers a critique of the field of sociology, observing that EuroAmerican perspectives have continued to dominate 
supposedly new sociological thought in an era of globalization theory (2007, pp. 62-68). While the South has become more written about in Northern social theory, it is still not, Connell argues, regarded as a place from which intellectual production might actually be taken seriously. Rather, the South continues to be the place from which data is gathered, to be reformulated in the North and assembled into nominally global (but really Northern) accounts. Overturning these hegemonies requires both critiquing those Northern accounts which masquerade as global, and paying proper attention to other perspectives that have been marginalized as the domain of parochial 'local' debates. The geopolitics of whose debates merit being played out on a global stage, and whose research becomes marginalised as parochial, is particularly powerful in the networks of area studies that have historically carved up the postcolonial world along lines that effectively reproduce 'a North American style of knowing' (Rafael, 1994, p. 91). In the case of Latin American studies, Alvarez, Arias and Hale (2011) grapple with the question of how to overturn the Northern domination of a field of research whose foundation was largely an effect of US Cold War interests. They suggest that what is required is both a de-centring of US American frameworks and a re-visioning of the region that incorporates Latin American ontologies and histories in all their diversity. Such a task is easier said than done.

While television scholars may not feel it is necessary to abandon the various projects, agendas and approaches of media studies in order to re-imagine and reconstruct an entirely new field, it is valuable to consider how these broader interventions into the geopolitics of knowledge might shift our perspectives on how and where television is best studied. The challenge, then is to engage theoretically with the ideas raised by Mignolo, Connell and many others to 'de-centre' research while also translating this spirit into the empirical study of contemporary television. It is by engaging with both of these strands in concert-empirically investigating television beyond the 'usual places' in such a way that responds to the call of cultural theorists to question our very assumptions about where television studies' 'usual places' should be-that more nuanced understandings, and fewer premature declarations, might be made about what television is, and where it is going. Sometimes, as in the case of variety television's long history of participatory publics and audience interaction, we need to reconceptualise our understanding of media's past as much as opening up our imaginations of the future. Why shouldn't the Philippines, in this example, be a vanguard space from which debates and models for the future of television is drawn? And how might Philippine television's history as always having been worthy of generative research be reclaimed?

It is encouraging and significant that in contemporary television scholarship, it is today quite unsustaina- ble for whole arguments about the nature or future of television-whether as a technology, as an industry, or as a complex of cultural practices-to be mounted without reference to the diverse and contingent histories that have constituted television around the world. But to simply collect global accounts of television is not enough, and nor should the purpose of such accounts be merely to intervene in debates and definitions wherein the United States or the United Kingdom are still assumed as the core models against which these 'minor' histories are contrasted. It is time for critical television studies to go one step further, and work towards a television studies which takes cross-cultural, multiple, peripheral, Southern, de-centered perspectives as a starting point rather than an admirable correction.

\section{Acknowledgments}

This paper draws from extensive research materials developed while working at the Centre for Critical and Cultural Studies, University of Queensland, with funding from an Australian Research Council Postdoctoral Fellowship and Discovery Grant with Professor Graeme Turner (DP110100075); my thanks to Graeme and our colleagues at the University of Queensland for their advice and feedback on this project. Research assistance was provided in Manila between 2009-2011 by Maria Jovita Zarate, Schedar Jocson, Mawen Ricohermoso and Fernan Talamayan. Thanks also to TAPE Inc., GMA Network and $\mathrm{ABS}-\mathrm{CBN}$ for their assistance and support.

\section{Conflict of Interests}

The author declares no conflict of interests.

\section{References}

Abu-Lughod, L. (2005). Dramas of nationhood: The politics of television in Egypt. Chicago, IL: University of Chicago Press.

Alvarez, S., Arias, A., \& Hale, C. R. (2011). Re-visioning Latin American studies. Cultural Anthropology, 26(2), 225-246.

Anderson, B. (1988). Cacique democracy in the Philippines: Origins and dreams. New Left Review, 1, 3-31.

Comaroff, J. \&. Comaroff, J. L. (2012). Theory from the South: Or, how Euro-America is evolving toward Africa. Anthropological Forum: A Journal of Social Anthropology and Comparative Sociology, 22(2), 113121.

Connell, R. (2007). Southern theory: The global dynamics of knowledge in social science. Sydney, NSW: Allen \& Unwin.

Curran, J., \& Park, M. (Eds.). (2000). De-Westernizing media studies. London: Routledge.

Curtin, M. (Ed.). (2010). Reorienting global communication: Indian and Chinese media beyond borders. 
Champaign, IL: University of Illinois Press.

Enriquez, E. L. (2008). Appropriation of colonial broadcasting: A history of early radio in the Philippines, 1922-1946. Quezon City: University of the Philippines Press.

Enterprise Innovation. (2014, July 18). Philippine broadcaster delivers digital content via mobile devices. Enterprise Innovation. Retrieved from http://www. enterpriseinnovation.net/article/philippine-broadcas ter-delivers-digital-content-mobile-devices- 1565068 075

Fernandez, D. (1996). Palabas: Essays on Philippine theater history. Manila: Ateneo University Press.

Ginsburg, F., Abu-Lughod, L., \& Larkin, B. (Eds.). (2002). Media worlds: Anthropology on new terrain. Berkeley, CA: University of California Press.

Goggin, G., \& Hjorth, L. (Eds.). (2014). The Routledge companion to mobile media. Abingdon, Oxon: Routledge.

Katz, E., \& Scannell, P. (Eds.). (2009). The end of television? Its impact of the world (so far). The Annals of the American Academy of Political and Social Science, 625(1), 1-235.

Katz, J., \& Castells, M. (Eds.). (2008). Handbook of mobile communication studies. Cambridge, MA: MIT Press.

Kraidy, M. (2010). Reality television and Arab politics: Contention in public life. New York, NY: Cambridge University Press.

Keane, M., Moran, A., \& Fung, A. Y. H. (2007). New television, globalization, and the East Asian cultural imagination. Hong Kong: Hong Kong University Press.

Mankekar, P. (1993). National texts and gendered lives: An ethnography of television viewers in a North Indian city. American Ethnologist, 20(3), 543-563.

McMillin, D. (2006). International media studies. Oxford, Oxon: Blackwell.

Mignolo, W. D. (2002). The geopolitics of knowledge and the colonial difference. The South Atlantic Quarterly, 101(1), 57-96.

Mignolo, W. D. (2011). The darker side of Western modernity: Global futures, decolonial options. Durham, NC: Duke University Press.

Ong, J. C. (2015). The television of intervention: Mediating patron-client ties in the Philippines. In J. Tay \& G.
Turner (Eds.), Television histories in Asia: Issues and contexts (pp. 144-163). London: Taylor \& Francis.

Paul Budde Communication. (2014). Philippines-Mobile communications, forecasts and broadcasting market. Bucketty, NSW: Paul Budde Communication.

Periabras, R. C. (2015, July 5). Pay TV market slow to grow, faces tough competition. Manila Times. Retrieved from http://www.manilatimes.net/pay-tvmarket-slow-to-grow-faces-tough-competition/1977 93

Pertierra, R. (2014). Localizing mobile media: A Philippine perspective. In G. Goggin \& L. Hjorth (Eds.), The Routledge companion to mobile media (pp. 42-52). Abingdon, Oxon: Routledge.

Pertierra, A. C., \& Turner, G. (2013). Locating television: Zones of consumption. New York, NY: Routledge.

Punathambekar, A. (2010). Reality TV and participatory culture in India. Popular Communication, 8(4), 241255.

Rafael, V. (1994). The cultures of area studies in the United States. Social Text, 41(Winter, 1994), 91-111.

Rofel, L. B. (1994). "Yearnings": Televisual love and melodramatic politics in contemporary China. American Ethnologist, 21(4), 700-22.

Sinclair, J. (1999). Latin American television: A global view. Oxford: Oxford University Press.

Soriano, C., Lim, S. S. \& Rivera-Sanchez, M. (2015). The Virgin Mary with a Mobile Phone: Ideologies of Mothering and Television Consumption in Philippine Television Advertisements. Communication, Culture and Critique 8(1), 1-19.

Spigel, L., \& Olsson, J. (Eds.). (2004). Television after TV: Essays on a medium in transition. Durham, NC: Duke University Press.

Straubhaar, J. (2007). World television: From global to local. New York, NY: SAGE Publications.

Turner, G., \& Tay, J. (Eds.). (2009). Television studies after TV: Understanding television in the postbroadcast era. Abingdon, Oxon: Routledge.

Turner, G. (2016). Re-inventing the Media. Abingdon, Oxon: Routledge.

World Bank. (2015). World development indicators: The information society. Retrieved from http://wdi.world bank.org/table/5.12

\section{About the Author}

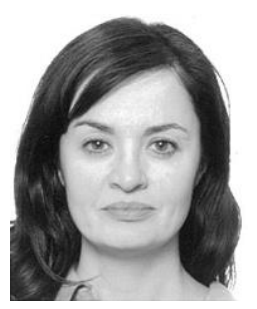

\section{Dr. Anna Cristina Pertierra}

Anna Cristina Pertierra is a Senior Lecturer in Cultural and Social Analysis at Western Sydney University. Her research uses ethnography to examine everyday practice, with a particular interest in media, consumption and urban modernities. Regionally, her work focuses on Cuba, Mexico and the Philippines. Recent publications include, with Graeme Turner, Locating Television: Zones of Consumption (Routledge, 2013) Cuba: The Struggle for Consumption (Caribbean Studies Press, 2011), and, with John Sinclair, Consumer Culture in Latin America (Palgrave Macmillan, 2013). 